\title{
Forms of subjectification: Rights and freedom as neoliberal politics in healthcare system. The Italian law on Living Will
}

OÑATI SOCIO-LEGAL SERIES VOLUME 10, ISSUE 6 (2020), 1133-1165: GOVERNING THE POLITICAL: LAW AND THE POLITICS OF RESISTANCE

DOI LINK: HTTPS://DOI.ORG/10.35295/OSLS.IISL/0000-0000-0000-1049

RECEIVED 15 AUGUST 2018, ACCEPTED 17 MAY 2019

\section{MATTEO FINCO* (D)}

\section{Abstract}

Health represents a context where it is possible to observe the relationship between individuals and society, namely which spaces of autonomy are left for the individuals and which social forces are exercised on them. If Critical Theory points out the mechanisms of a neoliberal matrix that makes individuals "subjugate subjects", Social System Theory allows to investigate how they are "included" in various spheres of society. Integrating these theories, we investigate mechanisms of subjectification on health. Moreover, through the analysis of the recent Italian law on advance directives and living will, we question if the claims of self-determination expressed by individuals could represent a form of "resistance" against neoliberal policies. Through a theoretical reflection and an analysis of the background and the juridical consequences of the law n. 219/2017, we conclude that the individual autonomy could be exercised together with responsibility towards others, balancing individual needs and claims with social solidarity.

\section{Key words}

Subjectification; right to health; DAT; living will; Italy

\section{Resumen}

La salud representa un contexto en el cual se puede observar la relación entre los individuos y la sociedad. Si la Teoría Crítica apunta a los mecanismos de una matriz neoliberal que convierte a los individuos en "sujetos subyugados", la Teoría de Sistemas Sociales permite investigar cómo éstos son "incluidos" en diversas esferas de la sociedad. Al integrar esas teorías, investigamos los mecanismos de subjetivización en el área de la salud. Además, a través del análisis de una ley italiana reciente, nos

\footnotetext{
* PhD in Social Sciences, Università degli Studi di Macerata (Italy). Postdoc researcher (PNDP/CAPES scholarship, Brazilian government) at UniRitter (Porto Alegre). Contact details: Campus UniRitter Zona Sul, Rua Orfanotrófio, 555, Alto-Teresópolis, Porto Alegre - RS, 90840-440 (Brazil). Email address: fincomatteo@gmail.com
} 
preguntamos si las proclamas de autodeterminación expresadas por los individuos podrían representar una forma de "resistencia" contra las políticas neoliberales. A través de la reflexión teórica y el análisis del contexto y de las consecuencias jurídicas de la Ley 219/2017, concluimos que la autonomía personal se podría ejercitar junto con la responsabilidad hacia el prójimo, equilibrando las necesidades y las reivindicaciones personales con la solidaridad social.

\section{Palabras clave}

Subjetivización; derecho a la salud; DAT (Disposizioni Avanzate di Trattamento); testamento vital; Italia 


\section{Table of contents}

1. Introduction: Health as a mirror of the relation individual/society..... 1136

2. Modern semantics: Freedom, equality, subjective rights 1137

3. Mechanisms of subjectification 1140

4. Critical Theory. Neoliberalism: Subjugated subjects ................................................... 1141

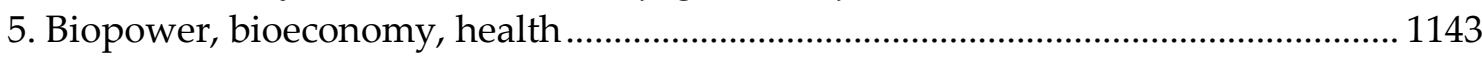

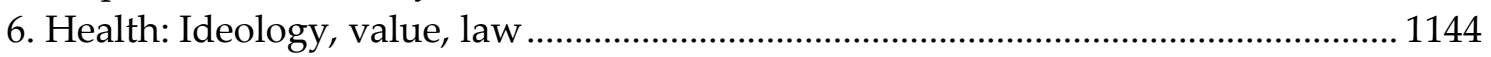

7. Systems Theory. World Society, persons/bodies, inclusion ...................................... 1145

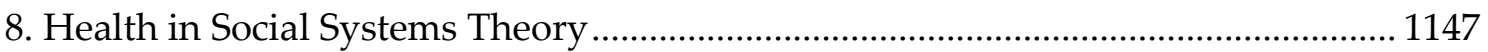

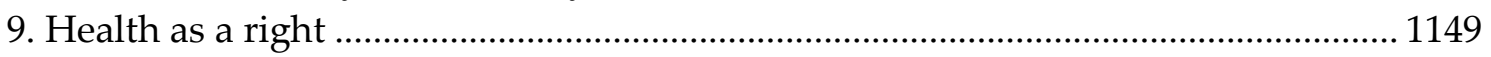

10. Italy: The law on "informed consent" and "advanced treatment decisions".

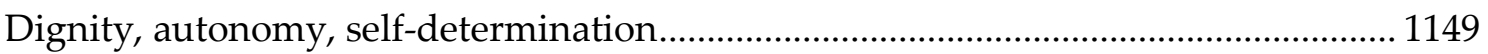

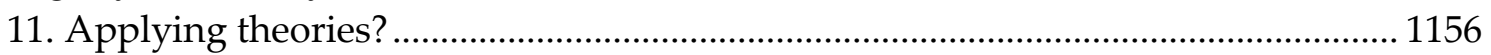

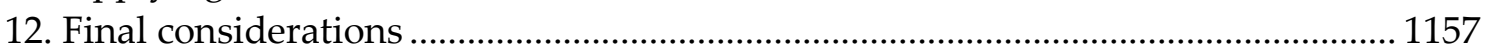

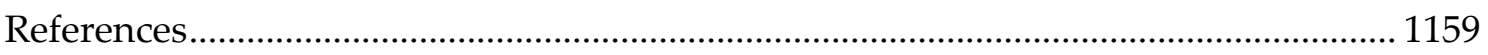




\section{Introduction: Health as a mirror of the relation individual/society}

If it is true that an exhaustive description of medicine as a social phenomenon - a sociological theory of medicine - is lacking (Corsi 2015b, 9), at the same time it is also true that human and social sciences pay constant attention to health. In fact, it is not clear what health is: the term certainly indicates the absence of diseases, disorders, problems. Moreover, the WHO provided a very broad and vague definition ("a state of complete physical, mental and social well-being and not merely the absence of disease or infirmity", Constitution of the World Health Organization, 1946). For this reason the approach to the topic can be very varied: we can deal with the organization of health and care systems, the relationship between patients and health personnel, policies related to prevention, and much more.

If we look at rights, we can see that generally the right to health is considered a human right, that is, a universal right without clear limits (i.e.: it is not limited to the request for treatments: also prevention is claimed). Moreover - as in every fields of contemporary society - there is a growth of the claims, both qualitatively and quantitatively. Claims are openly based on the assumption that individuals should be entitled of greater freedom and autonomy. In fact, the progressive "liberation" of the subjects from the conditioning and limits imposed by social reality is one of the features characterizing modernity: it is a principle and also a moral value, common to different theories, criticisms, movements. At the same time, it is also the result of a historical process that is hard to deny. A process that, if described only in general terms, could be interpreted in different ways. For example, the term "individualism" can indicate isolation and weakening of community ties, as well as the empowerment of individuals with respect to their own choices and actions, and so the possibility to express a "more authentic" individuality.

The article analyses the contemporary semantics related to freedom, autonomy, rights regarding health and well-being. The aims are: 1) looking at the supposed "dark side" hidden behind the increasing calls to freedom and autonomy of individuals; 2) questioning the concrete use that individuals and collectives make of these claims and their effects, in terms of both a greater "dependence" ("subjugation") from society and a possible authentic and responsible "freedom"; 3) doing this, it tackles one of the traditional problems (if not the original one) of sociology, that is, the relationship between the individual and society, trying to understand how this problem is currently "solved" in the realm of health.

In short, questioning health as a field where subjectivisation (the process of becoming an autonomous subject, with a specific identity) takes place, requires: a) examining neoliberal ideas, policies and practices in the health area (healthcare systems, individual choices and behaviors relating to health); b) analyzing if, in this area, are emerging new possibilities of "resistance" against neoliberalism, able to enhance individual autonomy and responsibility towards others, so balancing individualism and social solidarity.

If the theoretical analysis - which here considers two different orientations: the Critical Theory and the Social Systems Theory - deals with the first point mentioned above, the second one will be addressed by the examination of the recent Italian law concerning advanced medical directives. Our hypothesis is that are emerging new forms of 
"resistance", that could be identified within the same contemporary neoliberal and biopolitical processes and practices.

\section{Modern semantics: Freedom, equality, subjective rights}

Freedom and equality are probably the two most strongly advocated rights in modernity. Definitively consecrated by the French Revolution, they served to legitimize visions linked to natural law ${ }^{1}$ and the principle of free competition, and are also at the basis of the modern idea of individuality: an idea that emerged during the Italian Renaissance (XIV-XVI century) and that - explains G. Simmel - indicates

a state of inner and external liberation of the individual from the communal forms of the Middle Ages, forms which had constricted the pattern of his life, his activities, and his fundamental impulses through homogenizing groups. These had, as it were, allowed the boundaries of the individual to become blurred, suppressing the development of personal freedom, of intrinsic uniqueness, and of the sense of responsibility for one's self. (Simmel 1971, 217) ${ }^{2}$

For the individual, however, being an end in itself also implies a link with a larger totality: the idea of a "natural equality of individuals" that characterizes the Eighteenth century thus makes it possible within the social context the coexistence of the individuals' different demands and claims. With the rise of the modern State, of the liberal ideology, of democracy, of capitalism, natural law gives way to positive law: this one is created by the State and it is autonomous, changeable, unmarked by the influence of religion and distinguished from morality. The first expressions of the philosophy of fundamental rights and the increasing demands of individual rights (Peces-Barba 1993, 100-101) emerged. Alongside with the reversal of the relationship between individual and State - subjects become citizens - there is also the one between right and duty: if the archaic and traditional normative codes were characterized by duties (obligations), ${ }^{3}$ the modern ones (starting from the French and American Declarations of the XVIII century) are characterized by rights. The point is that it is mainly a matter of subjective rights: rights of the individual, which he/she can claim, that legitimize him/her autonomy with respect to the social context of origin and belonging.

In fact it is possible to find in modernity a semantic complex centered on the terms individual, subject, person: sometimes used interchangeably - even if each one of them has its own specificity - these terms have in common a characteristic "ambivalence"

\footnotetext{
1 “Solo ipotizzando uno stato originario senza società né stato, in cui gli uomini vivono senz'altre leggi che le leggi naturali che non sono imposte da un'autorità esterna ma sono ubbidite in coscienza, si può sostenere l'audace principio contro-intuitivo e chiaramente antistorico che gli uomini nascono liberi ed eguali" (Bobbio 1997, 126).

2 For Simmel the individuality means a relationship with the world but also that the individual is focused on himself and self-contained. He is a unity with a meaning in himself and, at the same time, it is related to something outside of itself, is a part of a totality.

${ }^{3}$ For example, the Ten Commandments, the Code of Hammurabi, the Twelve Tables: these are moral and law systems consisting of imperative rules, commands, prohibitions: in this sense Bobbio says that from some masterpiece, such as those of Plato, Cicero, Montesquieu, we can deduce that the primary function of the law is to compress, to restrict - not to widen - the spaces of freedom, because the codes of rules had the function to protect the group as a whole rather than to protect the individual (Bobbio 1997, 54-55).
} 
(Supiot 2005, 46-47) ${ }^{4}$ that configures the human being in the society at the same time as: a) indivisible, unique, ${ }^{5}$ but - just for this - similar to all the others; b) sovereign of himself - endowed with will - but also subject to the law; ${ }^{6}$ ) with a spiritual essence which makes him different from things, giving him dignity. ${ }^{7}$ We could trace back the first signals of this complex in the "navigation metaphor" described - referring to the Greek and Roman tradition (Foucault 2005, 248-249) ${ }^{8}$ - by Foucault. It consists, on the one hand, of the idea of a movement, of a subject's progression towards himself and, on the other, of the theme of the return, that is implicated in this movement. In this way the individual tries to formulate a personal answer/solution to the question about what is important in life, setting goals and ends, during a journey that represents an opportunity for learning, knowledge (savoir) but also a fragile art ("a fragile craft"), which allows to gain a distinctive "I" (Archimandritou 2015).

So we could find in the philosophical, juridical and sociological tradition this modern semantic complex, that we could call the individual-subject-person apparatus: it is the result of a set of conceptualities, practices, discourses, normative dispositions, ${ }^{9}$ which set the human being at the same time as something more and something less than what he/she is in his/her basic animal "immediate life", freeing him/her from the conditioning of the traditional society divided by classes, endowing him/her with subjective rights, making $\mathrm{him} /$ her the center of legal imputation because he/she is separated from the group. ${ }^{10}$

The modern subject is no longer the one we could find in the Roman law (ius), where subiecto ("placed under") indicated who was subject to a public or private power; the theory of subjective rights that developed between the Eighteenth and Nineteenth centuries, shifts the human being "from the 'object' of the norms" to a subiectum: (Orestano 1950, 151) it becomes the subject, their main character. The "'subject', alias the

\footnotetext{
4 “L'individu est à la fois l'unique et le semblable; le sujet est à la fois le souverain et l'assujetti; la personne est à la fois chair et esprit" (Supiot 2005, 67).

${ }^{5}$ From in (negation) and dividati (separated, separable).

${ }^{6}$ From sub-jectum as "jeté dessous": "il n'est pas de 'je' possible sans une instance garante du 'je' (l'État)" (Supiot 2005, 58).

7 "[I]l est devenu sacrilège de traiter les choses comme des personnes" (Supiot 2005, 59).

${ }^{8}$ Foucault talks about expressions like eph'heauton epistrephein, eis heauton anakhhn an, ad se recurrere, ad se redire, in se recedere, se reducere in tutum.

${ }^{9}$ We use here the word "apparatus" on the basis of the Foucault's concept of "dispositive": "What I'm trying to pick out with this term is, firstly, a thoroughly heterogeneous ensemble consisting of discourses, institutions, architectural forms, regulatory decisions, laws, administrative measures, scientific statements, philosophical, moral, and philanthropic propositions - in short, the said as much as the unsaid. Such are the elements of the apparatus. The apparatus itself is the system of relations that can be established between these elements. Secondly, what I am trying to identify in this apparatus is precisely the nature of the connection that can exist between these heterogeneous elements (...). In short, between these elements, whether discursive or non-discursive, there is a sort of interplay of shits of position and modifications of function which can also vary very widely. Thirdly, I understand by the term 'apparatus' a sort of - shall we say - formation which has as its major function at a given historical moment that of responding to an urgent need. The apparatus thus has a dominant strategic function" (Foucault 1980, 194-195). Also Agamben (2009) uses the term (see section 5).

${ }^{10}$ In the modern law, the concept of "subjective right" indicates the individual freedom of action (Habermas 1996).
} 
individual", is "conceived as a free and conscious person" and the subjective right is understood "as the power of the subject's will". ${ }^{11}$

This apparatus then shows that the individual is nothing but a consequence of modernity, and that the processes of subjectification - which have the double effect of "creating" the subject and keeping it subjected - anticipate liberal or neoliberal politics.

This does not mean underestimating other significant changes, above all those that are determined by the biopower: on the one hand political strategies that deal with the "species"; on the other hand, the fact that power adopts the language of normalization, management and control.

The object of power then becomes the life itself, which must be protected and intensified, ${ }^{12}$ but also and above all regulated, defined, normalised (and not just equipped with norms and rules). Politic is now the government of life, in all its aspects (work, production, family, survival, security) [Bazzicalupo 2003, 134-144]. This is achieved less and less through the exercise of violence, coercion, direct and authoritarian impositions: instead power tends to be "soft"; in modern society a "self-discipline" imposes itself. But it is - and it is worthy to underline - the result of two seemingly opposite tendencies: as N. Rose says, if between the 1500 and 1600 "explicit connections" appear "between the tasks of good government and the techniques of producing industrious, able, obedient, and disciplined subjects", through "a science, a knowledge and technique for producing and maintaining the good order of the population and of every person within it" (Rose 1999b, 225), in the XIX century

the constitutional doctrines of liberty, rights, and the rule of law proclaimed limits upon the use of state power to intervene into the lives of citizens, they presupposed an individual endowed with personal responsibilities for the social consequences of their acts and propensities for the self-regulation of conduct (...). The individual - in the Twentieth century - was to be integrated into society in the form of a citizen with social needs, in a contract in which individual and society would have mutual claims and obligations. (Rose 1999b, 227-228)

As a result, we have an individual political subject "whose citizenship is to be manifested through the free exercise of personal choice among a variety of marketed options" (Rose 1999b, 230). A subject called to decide, to choose, to make rational selections. ${ }^{13}$ An individual-subject-person who must be original, who finds in himself/herself his own foundation, and whose rights recognised as fundamental - the same rights that give fundament to the constitutional state - indicate this coexistence of freedom/liberty ${ }^{14}$ and equality: this is an individual that has the right to be equal to others precisely because of the possibility of distinguishing himself/herself, to be unique. ${ }^{15}$ The paradox of (modern)

\footnotetext{
${ }^{11}$ This formulation ("subjective right as power of the subject's will") is usually traced back to F.C. von Savigny, even if it does not appear in this precise form in his System of the Modern Roman Law (Orestano 1950).

${ }^{12}$ Biopower considers life "pointing to its defence, its growth, its empowerment" ["nel senso della sua difesa, della sua crescita, del suo potenziamento"] (Esposito 2003, 124).

13 "The self is not merely enabled to choose, but obliged to construe a life in terms of its choices, its powers, and its values. Individuals are expected to construe the course of their life as the outcome of such choices, and to account for their lives in terms of the reasons for those choices" (Rose 1999b, 231).

${ }^{14}$ About the difference between "freedom" and "liberty", see, among others, Cruz Balbuena 2018.

${ }^{15}$ It is the so-called "principium individuationis"; see Nietzsche 1993, 16.
} 
individuality consists in the possibility to be unique individuals, but only within the (modern) society (Corsi 2015b, 196). ${ }^{16}$

On this basis it is possible to see neoliberal policies and conditionings not as exceptions and deviations to the history, but as products of modernity, which are based on the same conditions that make it possible.

\section{Mechanisms of subjectification}

In order to analyze more closely the concrete effects of some evident processes and mechanisms that - in the wake of the call to autonomy, freedom and rights - condition the contemporary individuals in a binding way, we use here two different theoretical approaches. Apparently they are incompatible with each other: one is normative and tries to suggest solutions in order to modify the reality, while the other is descriptive and doesn't have any pretension to be critic. But the reason to use them is just this: without the pretense of combining them, we will try to shed some light on different significant issues, starting from the assumption that the semantics related to individual health and well-being is highly complex and that investigating it from different points of view could only provide more opportunities for reflection. So we could try to see if two completely different theoretical frames could give some useful insights and could provide a "common ground" to work on.

There are other reasons why we choose these theories and not others. One approach reconnects with a successful tradition in the history of social sciences, able to overstep the limits of academic knowledge, becoming popular in the same mass culture that it pretends to analyze and criticize. So it is interesting to see if the most recent contributions to this approach could "stand the test of time". The other approach, unlike the first, had no success outside academies and a very little one inside them. At the same time, it provide a complex but comprehensive interpretation of the modern world, due to a great variety of elements that it takes from other scientific disciplines (biology, psychology, philosophy, among others). So it could be interesting to see if it has something to say about specific themes. Moreover, it was scarcely applied to problems relating to health and healthcare.

The first approach we use is the so-called Critical Theory: it is an attitude that, on the basis of the Frankfurt School, tries to problematize the reality, to highlight critical issues, without renouncing to moral and normative statements.

The second approach is the Social Systems Theory (N. Luhmann): here the separation between theory and criticism is clear, because this approach doesn't pretend to evaluate or to propose solutions, to change reality. Instead, the idea is that the task of sociology, conceived as science, is to describe reality in the best way possible, that is, in a viable way,

\footnotetext{
${ }^{16}$ Identity is then a typical modern "tool": in every different situation and context it is necessary to always act in an individual (personal, specific, unique) way: see Luhmann 1995b. We should conceive "individuals as the product of their own activity, as self-referential historical machines, which determine with each autooperation the starting condition for further operations and are able to do this only through their own operations" (Luhmann 1992, 76). About individual, individuality and individualism, see also Luhmann 1995b.
} 
that could "explain" problems and phenomena that otherwise remain difficult to be formulated.

\section{Critical Theory. Neoliberalism: Subjugated subjects}

Philosophy and social sciences have been using the term "neoliberalism" since many decades. It has been described as an ideology - focused on the ideals of human dignity and individual freedom - but also as a set of political practices (blending state, market, and democratic institutions) [Silchenko 2017, 45]. It is not directly produced by a dominant class, but it results "from the quotidian experience of buying and selling commodities from the market, which is then extended across other social spaces, "the marketplace of ideas," to become an image of society"; an ideology not only related to the political sphere, "but to the entirety of human existence" (Read 2009, 26).

Neoliberalism, on the basis of the work by M. Foucault, could be considered a set of processes that extends the economic-contractual-market logic to all social and political relations, establishing a mode of "governmentality": a modality, an apparatus, an ethos, which represents a new configuration of power. Consequently, individuals are called to govern themselves. ${ }^{17}$

Indeed, the neoliberal governmentality is exercised outside the classical categories of sovereignty, of the traditional logic that opposes the rulers to the governed: now the subjects are in constant tension between the spaces granted for their conduct and the devices of power. Since the Eighteenth century, we could see the rising of more and more freedom (freedom of market, freedom for sellers and for buyers, free exercise of the right to property, freedom of discussion, freedom of expression, etc.). The art of government then presents itself as the product and the management of freedom in all these areas. It is an art that does not say "be free", but "I will give you the chance to be free" (Foucault 2005, 65). For Foucault this relationship/tension between the individual and the government is exercised within the market, the "place of veridiction and of structuring of the microphysical relationships of power/knowledge" ${ }^{18}$ The State doesn't lose importance, but it is subordinate to the market.

The problem of neo-liberalism is (...) how the overall exercise of political power can be modeled on the principles of a market economy. So it is not a question of freeing an empty space, but of taking the formal principles of a market economy and referring and relating them to, of projecting them on to a general art of government. (Foucault 2008, 131-132)

So neoliberalism is an "art of government" that, through institutionalized discursive practices, allows the management of behaviors by structuring in a pervasive way the possibilities of individuals, operating "indirectly", to steer their actions towards virtuous

\footnotetext{
17 "Neoliberalism is in the first instance a theory of political economic practices that proposes that human well-being can be best advanced by liberating individual entrepreneurial freedoms and skills within an institutional framework characterized by strong private property rights, free markets and free trade (...). [N]eoliberalism values market exchange 'as an ethic in itself, capable of acting as guide to all human action, and substituting for all previously held ethical beliefs', it emphasizes the significance of contractual relationship in the marketplace. It holds that the social good can be maximized by maximizing the reach and the frequency of market transactions, and it seeks to bring all human action into the domain of the market" (Harvey 2005, 2-3).

18 "[L]uogo di veridizione e di strutturazione dei rapporti microfisici di potere/sapere" (Castorina 2011, 10).
} 
practices that "free" their self-government and self-control (Manfré 2014, 48-49). Autonomy, initiative, ambition, investment in future, self-interest, calculation, achievement of the best possible result, individual freedom, consumption, risk, planning, privatization, and above all competition. The individual becomes - as formulated by a successful expression - "entrepreneur of the Self". ${ }^{19}$

This governmental rationality, based on an "entrepreneurial government", produces the neoliberal subject, which has two characteristics: a) is an individual person endowed with inalienable rights; b) is an economic agent steered by his own interest. In this way the market logic tends to "inspire" human behaviour and relationships: so efficiency and productivity become indispensable requirements. The subject is then productive as long as he/she obtains well-being and pleasure, tending to happiness. This is an active and "desiring being") who wants to realize him/herself. In order to do so, this subject works constantly, foremost on itself, never ending to learn (learning becomes a permanent process), to adapt itself to different situations, and always tending to overcome its limits. This is a subject that doesn't wait for the help of someone or something: instead, it can only count on itself, and it is responsible for itself (see Rose 1999a, 154). A subject called for constant comparison with others, and consequently to always respect some standards. If it doesn't act in the prearranged way, it would be excluded, isolated, it would be victim of shame.

Consequently, this neoliberal freedom is a constraint, a way of domination, different from the classical one: the contemporary subject is, as B.C. Han (2014b) writes, a "subjugated subject". It is subjugated - first of all - by itself. This biopolitical, neoliberal power - could we talk about neoliberal biopower? ${ }^{20}$ - no longer needs to act directly, through prohibitions, deprivations, repression: instead - behind the appearance of greater freedom, behind the seductiveness represented by a life that can be built through his/her own decisions - it makes individuals dependent on it. Power lets individuals believe to be "free projects": free to do, to act, to create. But, in this way, makes them "performance subjects", ready to exploit themselves (Han 2017a) ${ }^{21}$ and forced to attribute failures and disappointments only to themselves. Neoliberal power therefore no longer needs to suppress. On the other hand, it assumes a permissive form, but requires the individuals to be totally involved, to spend their time but also to involve their emotions. It invites to express themselves, to participate, to communicate, to be "transparent", to "invest" in themselves. Power "knows" that making individuals more and more independent from each other means isolating them, and, at the same time, makes revolts less likely and protests less effective (Han 2017b).

\footnotetext{
19 " $\mathrm{I}] \mathrm{f}$ there is a new subject, it must be grasped in the discursive and institutional practices that engendered the figure of the man enterprise or 'entrepreneurial subject' in the late Twentieth century (...). Neo-liberal man is competitive man, wholly immersed in global competition" (Dardot and Laval 2017).

${ }^{20}$ Another very interesting term is "biocapitalism" (Codeluppi 2008).

${ }^{21}$ Today, "the single individual, who no longer understands him- or herself as a subjugated subject ('subject to'), but as a project in the process of realizing itself (entwerfendes Projekt). That is its ruse: now, whoever fails is at fault and personally bears the guilt. No one else can be made responsible for failure" (Han 2017b, 10; see also Han 2012 and 2014a).
} 


\section{Biopower, bioeconomy, health}

Neoliberal policies and practices are also exercised in the sphere of health and more generally in that of life in a broad sense: this happens through devices, companies, organizations, institutions, technologies that act in the areas of health, medicalization, body care. Their fundamental resource is the control and the enhancement of the living beings (Castorina 2011, 17). In this sense, biopolitic ${ }^{22}$ and biopower ${ }^{23}$ - conceived as politics and practices concerning life and living beings - and neoliberal policies - which encourage the subject to self-government through a continuous work on himself - coincide. As a result we could see the rise of a bioeconomy, that is, a bio-technological and bio-genetic management of the living beings, through capitalization and financialization (Rabinow and Rose 2006). ${ }^{24}$ The personalization of treatments and medical behaviors thus becomes a reality, as the extension of the possibilities for intervention in new fields. This imposes to reconsider rights (and duties) related to the medical/health field, to rethink public policies related to health, and also to re-elaborate the ethics related to these sectors. It is particularly urgent to answer to questions and problems related to the role of pharmaceutical companies (which naturally seek profits and make significant economic investments). Even more it is important to address issues related to bioethics, both on the collective and the individual level. It is not just a matter of questioning what life is, when it begins, when it is good to intervene or leave things in their course: above all, genetics and biotechnology impose to question and rethink concepts as "human nature", "living beings", "dignity", "humanity".

The so-called medicalization ${ }^{25}$ describes well the influence of neoliberal and biopolitical logic on health. It means the diffusion of a merely organic conception of body and illness and then of the patient, and the potentially indefinite extension of medical, pharmaceutical and technical treatment. This extension leads to the continuous reformulation of some distinctions, like health/disease-illness and normality/abnormality-pathology (Castorina 2016). Beyond the questions related to the organization (and to the ideology that supports it) of the practices and social-health services, it is worthwhile to underline the risks deriving from the application of the economic-contractual logic to new sociomedical practices, with the insistence on the semantics of the "universalization of risk": above all, the indefinite extension of the interventions, the delegation to the market of sufferings and pain, the affirmation of a contractual model of exchange between who wants to be protected from risks and who supplies tools and resources for this purpose (Castorina 2016, 8-9), the transformation/reduction of the person from medical patient to user/consumer.

\footnotetext{
22 A politic that aims "to ensure, sustain, and multiply life, to put this life in order" (Foucault 1978, 138).

${ }^{23}$ A power "that exerts a positive influence on life, that endeavours to administer, optimize, and multiply it, subjecting it to precise controls and comprehensive regulations" (Foucault 1978, 136).

${ }^{24}$ The bioeconomy aims - through various powers and devices - to benefit from the modification of the boundaries between human, sub-human and super-human (Castorina 2011, 26).

25 "We live in a medicalized society, one in which we explain problems in medical terms. For example, responding to social encounters with heavy drinking is explained as alcoholism. Inappropriate behaviour in the classroom is labelled hyperactive disorder, or, if it involves learning difficulties, dyslexia. Suicide is explained in medical psychiatric terms, as is gambling. Often people's gender preferences, especially if they are homosexual ones, are explained as the outcome of medical abnormalities" (White 2002, 49).
} 
So this is important to question to what extent the economic-contractual-market logics should be applied to health: everything about health (treatment, drugs, organizations, etc.) could be considered not only simple "commodities", because human lives depend on them. This is important in order not to leave to the market the decision about what is "natural", right, fair (and what is not) and what is the difference between healthy and sick (Alfieri 2013, 22).

Obviously, biopolitic and biopower is much more than neoliberalism: Giorgio Agamben says that even human rights, actually are the basis of the legitimacy and sovereignty of the state, because "Declarations of rights represent the originary figure of the inscription of natural life in the juridical-political order of the nation-state" (Agamben 1998, 127). They thus "transfer" biological life into politics. Agamben also describes the current extreme phase of capitalism "as a massive accumulation and proliferation of apparatuses", that are "anything that has in some way the capacity to capture, orient, determine, intercept, model, control, or secure the gestures, behaviors, opinions, or discourses of living beings" (Agamben 2009, 14-15). So "massive processes of desubjectification" become the instrument of government of living beings: instead of free subjectivity and real identities, there is control, with the triumph of oikonomia, that is, "a pure activity of government that aims at nothing other than its own replication" (Agamben 2009, 22).

\section{Health: Ideology, value, law}

From the standpoint of Critical Theory, also health, like any other field (and even when it is matter of life and death), is invested by the logic of economy and of neoliberal governmentality: they require consumers, who should be involved subjects, active promoters and producers of practices, aimed to the continuous exploration of new possibilities.

In this sense, the affirmation of the ideology of healthism, ${ }^{26}$ centered on the imperative of health, could be considered as the result of the same neoliberal ideology. Health becomes a direct responsibility of individuals, a requirement - not to say an obligation - that can also constitute a signal of the overall condition of the individual: not only the absence of illness, but more general well-being in every area. Health becomes the main indicator of a satisfying and good life, not just one of the elements that makes it so; it becomes a "metaphor for everything that is good in life, not just one of the elements that makes it so; it becomes a "metaphor for everything that is good in life" that "reinforces the privatization of the struggle for generalized wellbeing" (Crawford 1980, 365). It rises to the rank of a moral value, which must be shared and inspire daily behaviors and lifestyles. On the contrary, if illnesses and problems appear, they will be traced back to the wrong choices of the individual. Effort, self-discipline and even personal reflection are the signals of the individual's responsibility about his/her own health. This could be seen, for example, in the diffusion of tools that allow constant monitoring of vital parameters (such as watches equipped with sensors that monitor blood pressure and heartbeats). As any other area, even for health, a greater concern generates more anxiety and insecurity. Above all, healthism reinforces and legitimizes a rhetoric and a semantics

\footnotetext{
${ }^{26}$ We conceive "healthism" as an ideology with perverse and paradoxical effects: there is no critical intent towards the public health systems. See Silchenko 2017.
} 
concerning the right to be informed about their own conditions, about possible treatments and the freedom to choose them (Henderson and Petersen 2000, 2-3). ${ }^{27}$ However, this doesn't necessarily mean that healthism is only a negative phenomenon: it could also represent an incentive to individual reflection and an occasion for a critical and responsible individual action.

In essence, here we deal not with biopolitical and governmental processes and practices, exercised on a collective level, for the management of the population and the species, and on the regulatory and normalizing function of the modern "continuum of apparatus (medical, administrative, etc.)" (Foucault 1978, 144). Instead, we deal with the mechanisms of subjectification/objectification that in the health field determine the difference health/disease-illness, influence and encourage individual behavior in the name of choices to be carried out continuously, open up new possibilities for individual's lives, redefining the concept of life (and death). The fact that life becomes the stakes of political struggles is considered here from the point of view of the demands, the claims, the needs of the individual, because what is claimed and serves as an objective is life, conceived as basic needs, concrete essence of man, realization of its potential (Foucault 1978). In other words, while not denying or underestimating the constricting effects of biopower and neoliberal subjugation, we look primarily at the new possibilities that, at the same time, now individuals have. Also, we look at the rights that now they can claim. ${ }^{28}$

In this sense, the analysis of the Italian case (section IV), related to the recent law on advance directives, informed consent and living will (testamento biologico) could provide an example of "subjective re-appropriation": namely one of the strategies that allows individuals to think about their own subjectivity without being victim of biopower and neoliberalism.

The hypothesis is therefore that not necessarily the processes of institutionalization and neoliberal economic dynamics subjugate individuals, neutralizing or preventing the exercise of "practices of freedom" (Castorina 2013a, 2013b).

\section{Systems Theory. World Society, persons/bodies, inclusion}

Niklas Luhmann's theory represents an unconventional approach to sociology. It uses contributions from very different disciplines and research fields, has a rich and specific vocabulary and, above all, stands out for its high complexity. Here we will not explain its fundamental concepts. We can just say that it is based on the assumptions of constructivism ${ }^{29}$ and that one of its fundamental distinctions is between "system" and "environment": the first term indicates a set of elements that distinguishes itself for a

\footnotetext{
${ }^{27}$ In this regard, the consequent downsizing of the authority of doctors is not to be underestimated.

28 "The 'right' to life, to body, to health, to happiness, to the satisfaction of needs and, beyond all the oppressions or 'alienation', the 'right' to rediscover what one is and all that one can be, this 'right' - which the classical juridical system was utterly incapable of comprehending - was the political response to all these new procedures of power" (Foucault 1978, 145).

${ }^{29}$ It is a broad and differentiated group of theories based on a common assumption: knowledge does not consist in the understanding of external reality "as it is", but corresponds to the "construction" of an observer.
} 
specific operation and that can distinguish itself from an "external" (environment): it is different and also recognize this difference.

The overall system of society is made of communication: therefore human beings are part of its environment. Consequently, society is not "made" of human beings. ${ }^{30}$ Moreover, human beings can be considered systems as psychic systems (consciences), that distinguish themselves according to their specific operations, that is, the production of thoughts. Also, they can be considered as biological systems (bodies). So, for a psychic system, the body (even the one of the same human being) is part of the environment, and the other way round.

Luhmann describes modern society as a World Society, characterized by unprecedented levels of complexity and contingency. It could not be described anymore through some traditional concepts and distinctions, such as center/periphery. It is instead a polycentric and polycontextural society, structured on functional differentiation: different subsystems constitute it and each one of them has a specific function. For example, the economy manages the problem of access to scarce resources (not everyone can possess everything at the same time); law provides generalized normative expectations, that are valid even when they are violated (that is, law does not prevent illicit actions, but says what happens after them); science produces knowledge; medicine treats diseases and illnesses; families and intimate relationships concern the person, that is, the human being as a communicative construct, the communication partner. The person is the form ${ }^{31}$ which serves as a reference for interaction and communication (consequently, persons are not bodies, i.e. living, biological organisms). Only the persons can communicate, participate in the social context. So only they are included in the different functional systems: ${ }^{32}$ they can spend money (economy), have a role in politics, take a legal action, and so on.

It is through communication that modern individuality emerges: the individual becomes "distinguishable" from others, he/she becomes a unique, different from any other one. Only in this way he/she can be recognized and then observed, in his/her normal and pathological (deviant) behaviors. Then inclusion in the different areas of society (communication) means adaptation to the logic (that is, the specific operation) of each subsystem. For example, in economy the fundamental criteria (what System Theory defines "code") is pay/not-pay, in science is true/false, and so on. Then inclusion is not considered a value, an ethical expectation, but a circumstance or a process. Therefore it is the inclusion that indicates whether the individual (person), from the communicative perspective, is relevant or not. From this perspective, the process of identification (the construction of the specific and unique individuality) is problematic: it no longer takes place on the basis of pre-established conditions, as in older societies (for example according to the class to which everyone belongs). The identity is now the result of a series of choices, actions, preferences and decisions of the individual. It is a process structured on the basis of claims (that is, claims of inclusion) that are satisfied or disappointed. This explains, among other things, why the modern individual cannot

\footnotetext{
30 This does not mean that Luhmann should be considered an "anti-humanist".

${ }^{31}$ About the concept of "form", see Spencer-Brown 2014.

32 "Person" differs from the concept of "role": the role-oriented communication is impersonal communication, while the person-oriented one is interpersonal communication. Therefore one person could have many roles. About "person", see esp. Luhmann 1995a.
} 
find the meaning in society: on the contrary, he/she has to find it by him/herself, in his/her own individuality (Luhmann 2015b, 58).

With modernity the range of possibilities for action (possibility to express preferences and formulating expectations, and then to take advantage of opportunities) expands. This is possible because traditional constraints based on the membership to a specific social class vanishes: now the individual can choose a profession, attend different social groups, access to different social roles. Undeniably this is not simple: the construction of personal careers, identities, positions in society, is a hard process for the individual. $\mathrm{He} / \mathrm{she}$ is always called to set goals, objectives, trying to realize them. Above all, he/she must give meaning to his/her existence and to act accordingly.

Within this theoretical framework - but trying to go beyond Luhmann's ideas - it is possible to say that the human being is included as an individual, a subject and a person. It is the apparatus already outlined that describes and determines the modern identity. This needs to always be otherwise, contingent, precisely because we live in a context characterized by contingency, imposes the necessity of a specific (personal) selfrepresentation as an individual personality, as an individual-subject-person who considers himself/herself - and is perceived by others - as an autonomous (individual) being, able to exercise his/her right (subject) to participate in society, to communicate (person). How could this happen? The answer, with Luhmann, is: dignity and freedom. They are the fundamental conditions to be included in communication, that is, in the modern society. They represent the "prerequisite" for the successful outcome of self-representation, for the socialization of the human being conceived as an "individual personality" (Luhmann 2002, 110). Dignity is important on the internal side of identity and self-representation. Freedom on the internal one. The former made a good self-representation possible, according to roles that someone can have in society. It is the awareness that someone can became and express "what he/she really is", identifying him/herself with his/her own person. The latter represents the free development of his/her individuality: it is the right to a space for a personal action, protected from violations and interference of the different systems and organizations, above all those of the State.

Then dignity, freedom and more generally rights - before that indispensable values - can be considered functional requirements for participation in society. Consequently, even more than a right, individuality becomes a necessity, a duty.

So, even if it is not conceived as a critical theory, Social System Theory could give a critical contribution: that is, describing contemporary society, it gives a picture where rights seems necessary tools of a society that produces the kind of individuals it needs in order to reproduce itself.

\section{Health in Social Systems Theory}

For Social Systems Theory the medical system ${ }^{33}$ has the function to intervene on bodies and minds suffering from diseases and illnesses (in the strict sense) or - more generically - from "deviations". ${ }^{34}$ It is a social system because everything related to health and care

\footnotetext{
${ }^{33}$ Luhmann uses both the expression "System der Krankenbehandlung" ("disease treatment system") and "Medizinsystem" ("medical system"). About the possibility to consider a specific "system of health", see Vial 2015.

34 That is, anything in the body that isn't considered as normal (Corsi 2015a, 12).
} 
(medical-scientific knowledge, personnel training, organizational-administrative apparatus, language used, doctor-patient interaction, etc.) is built within communication. This system, like any other, works on the basis of a distinction: in this case, health/illness, that permits to understand when it is necessary to act with a treatment. The problem is that the distinction illness/sickness - along with the corresponding status (sick/healthy) ${ }^{35}$ - is constructed by communication: the resulting semantic (concepts, terminologies, procedures), the creation of professional figures and expectations of various kinds, to which one can refer in order to understand what we are talking about (Corsi 2015a, 23), are constructed by communication to. Concepts like health, illness and sickness must be constantly reviewed, for many reasons: because they are too general (in this regard, is interesting the use of many concepts, not so much different from one another); ${ }^{36}$ due to the progress of technical and scientific knowledge, which constantly allows to discover and recognise new problems (for example, when are identified the origins of previously unidentified diseases - like viruses or bacteria - or when new problems emerge due to social changes - for example, eating disorders); also, we could observe a general tendency towards pathologization and medicalization, that is, the process by which nonmedical problems starts to be defined and treated as health and/or medical problems, usually in terms of illness or disorders (Conrad 2007). ${ }^{37}$ In fact, there is nothing that has not been associated (or will not be sooner or later) to some disease (Luhmann 2015a, 31). ${ }^{38}$ So what is relevant for the medical system is widened in an unpredictable way: it is extended to the whole life (Luhmann 2015a, 46) - both materially and temporally and every individual's behaviour becomes relevant. It is difficult to think that this does not encourage a continuous and eternal monitoring of one's own conditions.

The medical system has, at least, two peculiarities that distinguishes it from other systems: a) it depends on the "negative" value of the code: illness is undesirable compared to health, that is impossible to define and that can is not able to orient the action; ${ }^{39} \mathrm{~b}$ ) its function does not refer to society (system), but to its environment, that is, to human beings as bodies and consciences. Why? Because a system can exist only if its environment is available: then without consciences and bodies society cannot reproduce itself. It can only exist if there are psychic and biological systems that make communication possible. Human beings are essential for the existence of social systems (society, organizations, interactions), because without them every relation is impossible: no utterance, no information, no understanding. ${ }^{40}$ Therefore the function of the medical system is to steer individuals towards a state of wellbeing for their bodies and minds, towards their best conditions, in order to always be able to form an "organic and psychical basis" suitable for communication, letting them be persons. This characteristic (make persons possible) also belongs to another system: education (Luhmann 2015b, 61).

\footnotetext{
${ }^{35}$ But also about what is observable or understandable and what is not (or is not yet); see F.B. Simon 1994.

${ }^{36}$ For example "disease", "illness", "sickness"; see Zuppiroli 2005.

${ }^{37}$ We could think, among others, about psychological problems like learning disabilities. However, it should be noted that in recent decades we can also find examples of demedicalization, as for homosexuality and masturbation; see Biancheri et al. 2016.

${ }^{38}$ So, we could say that health doesn't exist: even when the doctor considers the patient healthy, he is just saying that there are still no reasons to treat him; see Vial 2014.

${ }^{39}$ Cfr. Luhmann 2015a, 42. A similar case is the system of education (which lacks a specific code).

${ }^{40}$ Communication is the outcome of a process made by these three element or phase: utterance, information and understanding; see Luhmann 1997.
} 
In order to respond to this need, the individual is thus encouraged to express increasing health claims: both in the healthcare area (more - and even more detailed - examinations, more attention from the healthcare personnel, more effective drugs and treatments, more detailed and wider health insurances, etc.) and also in law system, through requests for rights (right to health in a broader sense, but also other rights relating to it: patient rights, right to dignity, etc.: an inflation of claims). ${ }^{41}$

\section{Health as a right}

Claims related to rights represent a problematic and multifaceted context and a constant challenge for society (above all for law and politics, called to deal with it directly): because once a right has been ratified (even more when we it is defined as human or fundamental right) it is difficult to contain the claims against it; and also because legitimate claims represent a precondition for further claims (and this without the possibility to imagine what would be claimed in the future) [Longo 2001]. This leads to a sort of "explosion of rights" in all areas of life, and even to a "right to have rights": but not in the sense of $\mathrm{H}$. Arendt, that is, the right to live in a context where one is judged only on the basis of his own actions and opinions. ${ }^{42}$ Instead, this "right to have rights" seems to be conceived as a characteristic of the human dimension and of its dignity, as the result of the "attitude of fundamental rights to create a communication code, a tool that links people to each other". ${ }^{43}$

Nevertheless, the paradoxicality of this outcome (there is no limit to what could be claimed as a right) offers the opportunity to question about which spaces for action and self-determination are possible for individuals, and whether these spaces really represent the answer to their concrete needs - an answer, after all, free from the constraints of the social - or, on the contrary, if it is the result of the pressures of biopower and neoliberalism and/or of systemic conditions, such as those we have just analyzed. Without the pretension of providing an answer to this question - instead, of trying to better formulate (describe) these problems - we will analyze a specific case: the recent Italian law on the so-called "biological testament" (living will).

\section{Italy: The law on "informed consent" and "advanced treatment decisions". Dignity, autonomy, self-determination}

At the end of 2017 the Italian Parliament approved the Law n. 219 on "informed consent" and "advanced treatment decisions". It is generally defined as "the law about biological testament" or "about DAT" (Disposizioni Avanzate di Trattamento).

\footnotetext{
${ }^{41}$ In Luhmann's words, "Anspruchsinflation", that is, the request for more protections and guarantees. As we have seen in the previous section, the concepts of "subject" and "person" serve precisely to formulate the claims of inclusion in the different functional systems.

42 "We became aware of the existence of a right to have rights (and that means to live in a framework where one is judged by one's actions and opinions) and a right to belong to some kind of organized community, only when millions of people emerge who had lost and could not regain these rights because of the new global political situations" (Arendt 1966, 177).

43 "[A]ttitudine dei diritti fondamentali a creare un codice di comunicazione, uno strumento che mette le persone in relazione tra loro" (Rodotà 2012, 7).
} 
The parliamentary discussion had begun in 2016, bringing together various proposals already formulated. ${ }^{44}$ Two years of discussion and 3,200 amendments led to the resolution of the controversial points ("inviolability" and "unavailability" of human life, prohibition of euthanasia, artificial nutrition and hydration, prevalence of the doctor's decisions on the patient's will) [Lenzi 2018, 103] and the law came into force on 31 January 2018.

The premise of the law can be considered the sentence n. 438/2008 of Constitutional Court, according to which informed consent about healthcare is a "right of the person" based on the principles expressed in art. 2 (personal freedom), 13 (personal selfdetermination) and 32 (right to health) of the Constitution. The principle of selfdetermination has indeed solid foundations in Italian laws and jurisprudence (for example, in addition to the Constitution, the art. 38 of the founding law of the National Health Service, the Cassation sentence n. 2847 of February 9, 2010, etc.). However, implementation rules were lacking. Hence the impulse to create norms that were "first of all a law on consent and not only on the living will". ${ }^{45}$ In this way, the recognition of the anticipated decision is a logical consequence of the value of the patient's will (Lenzi $2018,113)$. So this law represents a concrete tool to guarantee this autonomy. At the same time, it tries to meet the right to health with that of self-determination, in the name of recognition of both the patient's autonomy of decision and the doctor's professional autonomy: then, sign in the name of the relational element (Lenzi 2018, 105).

The most clear aspect of the law is that through these provisions (DAT), that can be express in the form of a written document or through a video, Italian citizens can now decide in advance whether or not to receive certain medical treatments in a future when - due to illness or incapacity - they would not have the possibility to express their will. But the basis for this is the so-called "informed consent" (consenso informato), that is, the right to choose if receiving - or not - complete information about their own health conditions and to approve or not some specific treatments, both when they start and when it is necessary to decide if to continue or stop them. ${ }^{46}$ For example, they can refuse therapeutic obstinacy, deep sedation, artificial nutrition and hydration, in order to avoid unnecessary suffering when a recovery is not possible. Also they can plan, together with their physicians, their cares in the case of chronic diseases.

An important figure introduced by the law is the trustee (fiduciario), whom, however is not mandatory to choose. In addition, to this figure - that could take the place of the patient once he/she was unable to express himself/herself - is recognized its decisional autonomy: for example when the patient decisions have become over time, manifestly unreasonable and not applicable to that clinical situation or if new treatments have

\footnotetext{
44 The legislative proposals until then were the following: C. 1142 Mantero, C. 1432 Murer, C. 1298 Locatelli, C. 2229 Roccella, C. 2264 Nicchi, C. 2996 Binetti, C. 3391 Carloni e C. 3561 Miotto; a queste faranno seguito: C. 3584 Nizzi, C. 3586 Fucci, C. 3596 Calabrò, C. 3599 Brignone, C. 3630 Iori, C. 3723 Marzano, C. 3730 Marazziti, C. 3970 Giordano (Lenzi 2018, 102, in footnote).

45 "[P]rima di tutto una legge sul consenso e non solo sul testamento biologico" (Lenzi 2018).

${ }^{46}$ Thus implementing the provisions of the European Convention on Human Rights and Biomedicine (1996), signed but not yet ratified by the Italian Parliament, and also realizing the provisions contained in the European Charter of Fundamental Rights.
} 
appeared, doctor and trustee could decide together in a different way from what the patient decided (Lenzi 2018, 115).

The doctor's responsibility is another essential pillar: they must take into account the patient's will to refuse treatment. At the same time, doing this, they are free from civil and criminal responsibility, so respecting their professional autonomy. Moreover, the law contains a special section for minors and incapacitates, placed under the responsibility of parents or other special figures.

This law has the virtue of ruling on a matter not regulated until now, in a State where the public debate is strongly influenced by the Catholic Church. In fact, not only many Italians are Catholics or give importance to their Catholic roots, but Vatican State, geographically speaking, is in Italy. One of the traditional argument of religious movement and Church about topics concerning life and technology is the so-called "slippery slope argument". It is widely used also to prevent the promotion of DATs, that is still represented as a gateway to the legitimacy of euthanasia, ${ }^{47}$ even if the deliberate decision to end one's life simply because it is considered unworthy of being lived, regardless of the therapeutic possibilities, is neither foreseen nor facilitated by law 219, which

it is in fact clearly inspired by the following principle: on the one hand, to fully guaranteeing the patient's right to refuse any treatment, including those essential for his/her survival, enjoying the best assistance available; on the other hand, do not allow any conduct aimed at causing or accelerating death. ${ }^{48}$

Anyway, maybe the most important aspect of law is that it represent a concrete tool to mediate between interests, rights and claims of different subjects (patients, their families, doctors). So, we could say that now a legal vacuum is covered. The same formerPresident of the Italian Republic, Giorgio Napolitano, on 2014 "drew the attention of Parliament to the need not to ignore the problem of end-of-life choices, quoting the tragic suicide of terminal patients" (Testoni et al. 2014, 122).

Two cases, among others, show clearly how much Italy need a law on such subjects: those of Piergiorgio Welby and Eluana Englaro.

The former was a man, suffering from muscular dystrophy and unable to move, but with the full capacity to understand and will. In 2006 he asked to the President of Italian Republic Giorgio Napolitano to have the power to interrupt the therapy and the measures that kept him alive. The request was rejected just on the basis of the legal vacuum (see Trib. Roma, sez I civ., ord. 15-16 December 2006). He died just few days after this decision.

The second case was about a woman that "lived" for 17 years in a vegetative state (completely still and unconscious). The parents, who already knew her will in similar cases, requested to interrupt artificial feeding and hydration. This request was

\footnotetext{
47 See "Slippery slope argument". Encyclopædia Britannica [online]. Available from: https://www.britannica.com/topic/slippery-slope-argument.

48 " $[R]$ isulta infatti chiaramente ispirata al seguente principio: da un lato garantire pienamente il diritto del paziente di rifiutare qualsiasi trattamento, compresi quelli indispensabili per la sua sopravvivenza, fruendo della migliore assistenza disponibile; dall'altro non consentire alcuna condotta volta a provocarne o accelerarne la morte" (Paris 2018, 6).
} 
authorised by the Court of Appeal of Milan on July 9, 2008. The Court confirmed a previous decision of the Court of Cassation, establishing that the interruption of treatment can be allowed when the patient is in an irreversible vegetative state and if, during his/her life, he/she had expressed his opposition to such treatments. After an appeal by the Milan attorney general, rejected by the Court of Cassation, and the government's attempt to issue an ad hoc Decree law to prevent the decision from being made, Englaro died on February 2009.

Now law 219/2017 regulates about very delicate bioethical issues, made possible due to the scientific and technological progress, that has been opening new possibilities for individual choice and action. In fact, nowadays it is urgent to reconsider some fundamental questions and concepts, like life and dignity - in particular human dignity. Previously, in this regard the legal instruments were limited, on the one hand, to the right to refuse treatments, enshrined in the second paragraph of art. 32 of the Constitution; ${ }^{49}$ on the other, to the absolute unavailability of life by others, a circumstance considered as crime. ${ }^{50}$

In general, related to the so-called "end of life" - about the health treatments to undertake in the final phases of life, when it has been established that the recovering is no longer possible - we can identify two different ethical-juridical approaches. The first one tends to consider human dignity as a subjective matter: it is the individual who sets its limits (for example, we could think about abortion and the different forms through which a "death with dignity" could happen); the second one, on the contrary, tends to consider the dignity an objective question, determined by ethical-religious precepts. Paradoxically, these orientations, taken to the extreme, could configure, on the one hand, a "right to die", and on the other, a "duty to live" (Losurdo 2018, 3).

If the reference to dignity is indispensable in order to decide on such delicate issues, at stake here there are also such fundamental concepts as "autonomy" and "selfdetermination": they refer to the possibility for the individual to decide about him/her own destiny, carrying out the necessary actions to realize it.

The Italian law on DAT does not provide specific formulations, but ratifies subjective rights by providing the tools to achieve them, taking into account - at the same time the relational element, i.e. the overall relationships between patients, doctors, trustees and close relatives (Losurdo 2018,4). This attitude reflects the approach expressed in the Italian Constitution, where dignity is conceived as a relative value, that concerns the concrete position of the person within the social relationships. It is not a value that could be established only by individuals on their own, because it originates relational commitments, since the recognition of the dignity to someone depends from his/her

\footnotetext{
49 “La Repubblica tutela la salute come fondamentale diritto dell'individuo e interesse della collettività, e garantisce cure gratuite agli indigenti. I Nessuno può essere obbligato a un determinato trattamento sanitario se non per disposizione di legge. La legge non può in nessun caso violare i limiti imposti dal rispetto della persona umana" (art. 32 of Italian Constitution).

${ }^{50}$ Art. 579: "Chiunque cagiona la morte di un uomo, col consenso di lui, è punito con la reclusione da sei a quindici anni"; art. 580 c.p.: "Chiunque determina altri al suicidio o rafforza l'altrui proposito di suicidio, ovvero ne agevola in qualsiasi modo l'esecuzione, è punito, se il suicidio avviene, con la reclusione da cinque a dodici anni. Se il suicidio non avviene, è punito con la reclusione da uno a cinque anni, sempre che dal tentativo di suicidio derivi una lesione personale grave o gravissima".
} 
fulfillment of "imperative duties of political, economic and social solidarity" (Losurdo 2018, 9-10). ${ }^{51}$ Dignity

is realized and makes sense in social relationships and not in the private sphere (...). The referent of the human person is not the egoistically conceived individual (the premise of mere freedom), but l'homme situé, the social, political man, active part of a society.52

Ultimately, the law stands out for its "intrinsic subjectivistic pluralism" in the name of the sustainability of the care relationship, ${ }^{53}$ realized through the informed consent, that, however, "it is not conceived as an absolute principle, but depends on science and medical ethics", because it allows the doctor to "refuse therapies or treatments requested by the patient that do not satisfy the leges artis". ${ }^{54}$ So the law attempts to contain the aforementioned phenomenon of the "inflation of claims", which is particularly evident in healthcare. It does this by safeguarding room for the doctor's autonomous decision, since the technical-scientific aspects prevails over the individual dimension (Busatta $2019,109)$.

For these reasons, this law allows to reflect on the foundations of the two opposite cited orientations (subjectification vs. objectification of dignity) and on the right of selfdetermination, which is now recognized to Italian citizens in a wider way. As we saw in the previous sections, self-determination is a value/claim/right - a requirement essential for the modern individual.

Therefore self-determination - a legal-political category of the Nineteenth century that indicates the right of individuals and peoples to decide their own destiny (Busatta 2019, 13 ) - is connected to the concept of "sovereignty": it indicates that the individual is "sovereign on himself/herself", that is entitled to decide about his/her own existence. Here, unlike autonomy (Busatta 2019, 32), ${ }^{55}$ the relational element is not present. If the Italian law on DAT recognizes the patient's right to exercise their autonomy (through anticipated treatment provisions and shared care planning), it does not let them to fully and completely self-determine themselves, because the law intends to integrate their will with that of doctors, trustee, family, trying to harmonize the decisional autonomy of the patients with the therapies and the ethics of other people involved (Losurdo 2018, 1516).

Moreover, the right to informed consent "represents a limit for the person and his/her decisions: it implies a qualified, relational, shared choice" (the so-called "therapeutic alliance"). .56

This law, however, contains ambiguities concerning patients unfit to plead. First of all, the conflict between the patient's desire and his/her right to refuse treatment and the

\footnotetext{
${ }^{51}$ Art. 2 of Italian Constitution is about "doveri inderogabili di solidarietà politica, economica e sociale".

52 "[S]i realizza e ha senso nella vita di relazione sociale e non nella sfera privata (...). Il referente della persona umana non è l'individuo egoisticamente inteso (il presupposto della mera libertà), ma l'homme situé, l'uomo sociale, politico, parte attiva di una società" (Morrone 2018, 10).

53 “'[I]ntrinseco pluralismo soggettivistico' sostenibilità della relazione di cura” (Busatta 2019, 99).

54 "[È] inteso come principio assoluto, ma incontra il proprio limite nella scienza e nella deontologia medica"; "rifiutare terapie o trattamenti richiesti dal paziente che non soddisfino le leges artis" (Busatta 2019, 105).

${ }^{55}$ See also Kant 2013, and Hegel 2019 about his theory of recognition.

56 "[R]appresenta esso stesso un limite per la persona e le sue decisioni: implica una scelta qualificata, relazionale, condivisa" (Morrone 2018, 11).
} 
doctors' conscientious objection remains a problem (Morrone 2018, 17). The Court of Pavia questioned the constitutional legitimacy of the law about the possibility for the trustee - if treatment decisions were not formulated - to refuse the treatment necessary to keep the person alive, without requesting the authorization to the judge (Busani and Smaniotto 2018). Also the law does not deal with those cases where an individual without the possibility to recover - but rather condemned to a life characterized by degrading situations - decides to end in a foreign state, where the necessary procedures are legal. This circumstance cannot be made equivalent to euthanasia. In fact, the penal code punishes ${ }^{57}$ both those who facilitate the accomplishment of a suicide and those who determine or reinforce the purpose of someone to make it happen. These are considered crimes, although we are talking about very different actions, and even if - from an ethical point of view - the behaviors that realize the death could be considered good, and even if the boundary between moral participation and material facilitation can be subtle. This is a current and urgent problem: in Italy a prosecution is currently under way against a well-known politician, Marco Cappato, charged for having facilitated the suicide of a man suffering from irreversible invalidating pathologies, simply by carrying him to a Swiss clinic where he legally died. ${ }^{58}$ Even the Italian government decided to intervene, bringing a civil action against Cappato (Corriere della Sera 2018). At the moment a decision on the matter has not yet been taken: the Milan Court of Assizes raised the question of the constitutionality of article n. 580 of the Criminal Code, asking to make criminally not relevant the facilitation of suicide when it did not affect the victim's decision. On October 24, 2018, the Constitutional Court, with a very uncommon decision (Ord. n. 207/2018), ${ }^{59}$ conceded to the Italian parliament one year to make a law taking into account cases like this one. If, at the end of this period, set at 24 September 2019, any law will be made, the Constitutional Court will decide on the case (Constitutional Court, Ord. n. 207/2018).

However, the constitutional doubt of raised by the Milan Court of Assizes is important also for another reason: recalling the law n. 219, where this guarantees "the right to choose to end him/her own life in a state of deep sedation in the case of suffering that is not responding to treatment", ${ }^{\prime 0}$ the Court argues that there would be essentially an unreasonable difference in treatment between patients who, kept alive by an artificial support treatment, may, under certain conditions, decide to end their existence by interrupting such treatment, and those who could not do so because the help of others would be essential for this purpose. ${ }^{61}$

Other problems about the law n. 219 have been highlighted by the Consiglio di Stato the highest court for legal-administrative consultancy and protection of justice in public administration - called to reply to some questions, submitted by the Italian government, about the law on living will. The Special commission of the court, among other things, affirms: a) the necessity to create a national database to "collect" (and not simply

\footnotetext{
${ }^{57}$ See note 52.

${ }^{58}$ In this case, the Court of Assizes of Milan raised a question of constitutional legitimacy of art. 580 of the Penal Code. The ruling of the Constitutional Court is now awaited.

${ }^{59}$ A decision inspired by the German model of the Unvereinbarkeitserklärung (Paris 2018, 9).

60 " [I]l diritto di scegliere di porre fine alla propria vita in stato di sedazione profonda nel caso di sofferenze refrattarie alle cure" (Court of Assizes of Milan, Ord. 14/02/2018).

${ }^{61}$ On the appeal of Court of Assizes of Milan, see also Tripodina 2018.
} 
"register") the DAT (eg: local databases in the municipal offices are not enough), in order to make the database an effective tool; $b$ ) that even people not registered in the National Health Service (SSN) - like migrants and foreign people - should have the right to register the provisions; c) that there is no need of a standard model for the DAT: everyone should be free to include the recommendations he/she prefer (for example about specific treatments, sicknesses, circumstances, etc.); d) that it is not mandatory to choose a trustee; e) that the information received from doctors should be clear and adequate: everyone should be well informed and aware about the consequences of his/her choices; $f$ ) about the right to privacy, that only the treating physician and the trustee should have the access to DATs.; g) that a monitory is "crucial" in order to provide corrections (Cons. St., comm. spec., 31 luglio 2018, n. 1991).

One year after the promulgation of the law, it is worth questioning its usefulness. In fact, many see it as a partial failure. A map available online, created by the Luca Coscioni association (Associazione Luca Coscioni n.d.), monitors the dissemination of places where it is possible to deposit the DAT. Although they are rising, there is still much to do in this regard. More generally, there are many doubts about the diffusion of knowledge of the possibilities made available by law n. 217. The results of a survey, carried out in 2018 in the Lombardy region (the most populous, with over 10 million inhabitants) [Focus MGMT-Vidas 2018], show that many people still do not know the contents of the law; that for many of those who have heard about it is not clear the concrete conditions to realize the DAT; that biological testament and euthanasia are often confused; that there is a clear polarization of opinions among right-wing voters, who declare themselves against the law, and left-wing voters, in favor; and that almost half of the people interviewed do not want to face the problem of having to choose aspects of their end of life because this subject makes them uncomfortable. The percentage of those who have not yet drawn up the "living will" is exemplary: $97 \%$ of the sample analyzed. These results confirm different researches conducted in other countries that highlight a fact: although the advanced treatment decisions are elsewhere long since used, ${ }^{62}$ their usefulness and effectiveness are limited. There are different reasons for that (Fagerlin and Schneider 2004): high costs; scarce awareness, indecision, doubts and superficiality on the part of patients; little involvement of doctors. ${ }^{63}$ All this generates a scarce effectiveness in guiding the decisions of the doctors and a general inconsistency of the same decisions. ${ }^{64}$

So, if it is true that the law no. 219/2017 represent the answer/reaction of the political system to solicitations coming from society (in a broad sense: civil society, opportunities made available by technology, etc.), it is possible to discuss whether this could be considered an attempt to "provide rights" to citizens - rights that could be exercised

\footnotetext{
${ }^{62}$ For example, in the USA, see Crist 2017.

63 "[E]mpirical studies demonstrate that: the PSDA has generally failed to foster a significant increase in advance directives use; it is being implemented by medical institutions and their personnel in a passive manner; and the involvement of physicians in its implementation is lacking" (Fagerlin and Schneider 2004, 32).

64 "In 4,804 patients, only 90 had a directive that gave a specific instruction, only 36 of these aimed to direct life-sustaining care, and only 22 of these noted preferences to forgo life sustaining treatment in the patient's present medical circumstances. Even if all of these had been noted and had been rigorously followed, the effects upon the overall population would have been imperceptible" (Teno et al. 1997, 11).
} 
with a high degree of autonomy - or if, on the contrary - just behind the "mask" of rights - it is a "product" of biopower and neoliberalism. From our point of view, the question remains open.

\section{Applying theories?}

Are Critical Theory and Social Systems Theory useful to analyze the law 219/2017?

Let's start saying that, on the one hand, these two theories don't seem to be compatible: the former, beyond the criticism, does not seem able to offer "solutions" or "loopholes" applicable on a large scale, nor a quite clear "vision" of a desirable future that would benefit the majority of people. On the other hand, the latter provides descriptions and avoids moral evaluations; it understands social phenomena as products of a complexity that does not allow to link, in a two-way correspondence, specific cases to specific reasons. Moreover, it is a theory that refuses classical concepts, such as that of progress, binding the future to a pre-established path (first of all about freedom and rights). Maybe it is true that some "tools", such as a law, should be evaluated retrospectively, for the concrete use made of them. In this sense, future empirical researches on the use of advanced treatment decisions ${ }^{65}$ will undoubtedly help to establish whether or not we are facing the exercise of a right that made possible the expression of the deeper and more personal feelings of individuals.

However, an observation seems necessary: the debate on the "end of life", like any ethical debate, only re-proposes the eternal problem - eternal because unsolvable $\mathrm{n}$ of the relationship between individual and society. This problem underlines the disorientation of the modern individual about his/her own death, but also the disorientation about the tools that could manage it. Often people don't know how to use them and sometimes even don't know if considering them desirable or not. In fact, new possibilities cause uneasiness. We can observe that it is an expression not only of the conflictual dimension between the individual and society, namely between human needs and desires on the one hand, and systemic conditions to be realized on the other. It is also the unequivocal sign of something we could call the transfer of death in the social sphere (politics, law, medicine are called to question itself about it): death now is not conceived anymore only as an organic and natural fact, but as something that is possible to fight, delay, question, manage. Thus we could detect, at the same time, a process of politicization of death on the one hand and one of politicization of life on the other (Agamben 1998): then both of them have to be reconsidered. An external observer as science (sociology, whatever is the theory used) cannot decide whether or not these represent the opportunity for the exercise of an autonomous and creative action, meaning a free but also informed, conscious and responsible action. It could only be a personal decision. And again: the clash between subjective experiences and social logics ends up questioning the overall social context, making the functional systems "areas of unsafety" as a consequence of individual claims (Caramaschi and Capanna Piscè 2008). If the society will not able to react to this uncertainty and unsafety, the consequence could be a crisis of their legitimacy.

\footnotetext{
${ }^{65}$ Appeal whose ease of access varies across the territory, given that the instructions must be deposited at the Municipalities or at Local Health Authorities, which must establish specific registers in this regard.
} 
Finally, coming back to individuals: the disorientation we described is even more dramatic as it becomes increasingly hard to identify references, orientations, social responses - outside religion and its classical precepts - which nevertheless are founded on dogmatics and semantics that are often not useful for finding an explanation for the changes (not to mention to propose solutions or some reactions). This is one of the effects of functional differentiation of modern society and of the correspondingly emerging individuality. Perhaps it is no coincidence that nowadays it is easier to find guidelines on ethical issues - however often vague guidelines - from political movements that are strongly inspired by concepts such as identity, country, nation, security: even if it is a traditional and apparently inadequate semantics, it is still firmly linked to the "community", to a collective dimension. If alternatives lack, this semantics could be considered an appropriate reference to find a meaningful difference between life and death; a difference which is not possible to explain as an organic matter, but deal with the reality of communication, that is, the society, that can only be can only be a nothuman". ${ }^{66}$

So, we think that the function of the theory is not to be applied to concrete cases: whatever theory could (and should) only provide a general framework, a context, a background, to describe society and represent it in all its contradictions. But we think that the contribution that the theories proposed here give us are clears. Both highlight that in the contemporary society the individual is called to decide: its increasing autonomy - although it can be conditioned, manipulated, controlled in various ways as emphasized especially by the Critical Theory - is associated - as the System Theory show - with a greater responsibility and a wider range of opportunities. So being free is a task for modern individual. He/she cannot do otherwise, but can try to fulfill this function in an increasingly varied and personal way, using his/her own intelligence and culture consciously. Subjectification, in other words, can be considered a condemnation or a task to be performed.

\section{Final considerations}

The question whether now adays evident claims inflation of rights could be explained as the outcome of biopower and neoliberalism, leads to examine the semantics about life and death. We believe that the analysis made here provides some points for a further reflection. Below we only sketch some considerations from which could be possible to keep on this research.

The idea that life - especially human life - has an intrinsic value, beyond the economic and instrumental ones that undeniably it assumes, can be considered one of the few almost universally shared ideas in the contemporary world. This doesn't mean that there is a universal agreement about the content and the characteristics of this value. In any case, any agreement is not sufficient to avoid tragic choices and painful conflicts (even intellectual ones). See, for example, the recent case of Alfie Evans, a two-year-old English boy who died because of an incurable illness and whose story was the focus of a conflict between his parents - who wanted not to interrupt the procedures that allowed him to stay alive, despite having been in a semi-vegetative state for more than a year - and his

\footnotetext{
${ }^{66}$ See the already illustrated distinction between "system" (society=communication) and "environment" (which includes human beings).
} 
doctors - who wanted to avoid therapeutic obstinacy, not only because a recovery would have been impossible, but also to prevent unnecessary and "inhuman" suffering (BBC 2018). This is an example - similar to many others (i.e. the ones mentioned in section IV) - of the limits of law when clear rules lack or where the scientific evaluation is not fully convincing (see Zagrebelsky 2018). In this sense, expectations - and the concept of functional differentiation by Social Systems Theory supports this hypothesis - can only be addressed to the political system, which has the function to create norms. On the other hand, avoiding systemic dedifferentiation would be desirable, but it is not always possible (see esp. Luhmann 1997).

The individual-subject-person apparatus seems to provide a key to conceive the modern individuality (and consequently the question about the identity). This tool - which connects social processes and cultural phenomena - suggests that health is an area - if not the one par excellence, precisely because it concerns life and death - where individual human beings can make choices and can act in a way that is the most personal, creative and closer to their feelings way. The fact that, alongside this possibility, we find binding actions and processes, aimed to control and "exploit", should therefore be seen as "the other side of the coin", inevitable (in the sense that it is an historical product) but at the same time not "unavoidable" in the future.

We therefore believe that this apparatus does not represent something "good" or "evil" in itself: it is a product, a result, that has both positive (simplifying: greater freedom) and negative effects (more effective conditioning). ${ }^{67}$ The fact that "only modernity makes individual self-preservation the presupposition of all the other political categories, from sovereignty to freedom", ${ }^{68}$ is something that should be accepted, because it explains biopower and neoliberalism, but that not necessarily binds the future. At the same time, the very criticism about biopower is already an act of freedom (Alfieri 2013).

We say that the claims about health could see as a "mirror" to interpret the relationship between individual and society and the individual use of the achievements obtained (see esp. Benasayag 2010). Health is at the center of the claims and interests, made by the individuals but also by systems. Individuals claim for more freedom and autonomy, in order to realize a "sovereignty over themselves". At the same time, politics, institutions, market entities (and everything that could be indicated by the term "power") in order to survive depend on the management and regulation (governmentality).

Then our analysis of the recent Italian law on informed consent and advanced treatment decisions, considers this law as the intention to provide the possibility for the exercise of individual autonomy without forgetting responsibility and relationship. Moreover, in this law we notice an attempt to find a balance between the individual level and the

\footnotetext{
67 The "abandonment" of the "person" has been signalized as a desirable goal, given the "not-human" outcomes it may lead to, for example by dividing human existence into personality levels that include only the adult individuals in good health; this due to a sort of process of "depersonalization" of the body, which makes the latter nothing more than a "thing", in addition to dividing humanity into people and non-persons, thus making the status of the person a temporary property; see Esposito (2007 and 2014), who analyses H.T. Engelhardt (1986) The Foundations of Bioethics (New York, Oxford University Press) and P. Singer (2000) Writings on an Ethical Life (New York, Ecco Press).

68 "[S]olo la modernità fa dell'autoconservazione individuale il presupposto di tutte le altre categorie politiche, da quella di sovranità a quella di libertà" (Esposito 2004, XIII).
} 
social one, between "individualism" and society, through relationship, despite neoliberal and biopolitical processes.

In our opinion, the theories here used show the importance and the necessity to develop "a complex thought": complex as the reality it tries to interpret. This thought should be characterized by "multiplicity" and should be able to interpret old and new forms of biopower and neoliberalism, which tends to reduce health to an "individual capital", to manage not only life but also death, considering fragility merely a negative feature. At the same time, this thought should try to go beyond the "humanist rhetoric" (which does not seem able to provide satisfactory solutions up to now), and the utilitarianism (Benasayag 2010, 17). It is necessary to go beyond the classic dichotomy between "the citizen endowed with inalienable rights and the economic man guided by self-interest", that is, the "man as 'end"' and the "man as 'instrument" (Dardot and Laval 2017). At the same time, we need to

invent effective and credible critics, therefore not commodifiable and truly radical. ${ }^{69}$

Finally, only a complex thought could represent a "reaction" of a very different kind from that one given today by populist political parties and movements: ${ }^{70}$ in their attempt to provide reassuring answers, they can only simplify - when not to mystify - reality. This could be understood, and maybe justified too, but it often occurs at the expense of the "freedom" that individuals nowadays claim more than ever.

\section{References}

Agamben, G., 1998. Homo Sacer: Sovereign Power and Bare Life. Stanford University Press.

Agamben, G., 2009. What Is an Apparatus? And Other Essays. Stanford University Press.

Alfieri, L., 2013. Prefazione. In: R. Castorina and G. Roccheggiani, eds., Paradossi della fragilità: Critica della normalizzazione sociale tra neuroscienze e filosofia politica. Milan: Mimesis, 9-25.

Archimandritou, M., 2015. A Fragile Craft: The Principium Individuationis and the Law. Oñati Socio-Legal Series [online], 5(3), 895-918. Available from: http://opo.iisj.net/index.php/osls/article/view/457/727 [Accessed 29 May 2019].

Arendt, H., 1966. The Origins of Totalitarianism. New York: Harcourt, Brace \& World.

Associazione Luca Coscioni, no date. Mappa dei registri dei testamenti biologici [online]. Available from: https://www.google.com/maps/d/viewer?mid=1ta z91xgyelWSQu02r16jwQJ48\&ll=42.88990436632566\%2C14.482859639690787\&z=6 [Accessed 29 May 2019].

\footnotetext{
69 "[I]nventare modi della critica che siano efficaci e credibili, dunque non mercificabili ed effettivamente radicali" (Donaggio 2014, 20).

${ }^{70}$ We deliberately avoid categories such as "right" and "left", both because history shows that populist characteristics could be manifested by movements of both kind; and because - once again - contemporary society seems to be more complex than what this distinction could express.
} 
Bazzicalupo, L., 2003. Ambivalenze della biopolitica. In: L. Bazzicalupo and R. Esposito, eds., Politica della vita: Sovranità, biopotere, diritti. Rome/Bari: Laterza, 134-144.

BBC, 2018. Who was Alfie Evans and what was the row over his treatment? BBC [online], 28 April. Available from: https://www.bbc.com/news/uk-englandmerseyside-43754949 [Accessed 29 May 2019].

Benasayag, M., 2010. La salute ad ogni costo: Medicina e biopotere. Milan: Vita e Pensiero.

Biancheri, R., et al., 2016. La prospettiva di genere, la medicalizzazione della vita e la digitalizzazione dei percorsi di salute. In: F. Corbisiero and E. Ruspini, eds., Sociologia del futuro: Studiare la società del ventunesimo secolo. Padua: CEDAM, 177195.

Bobbio, N., 1997. L'età dei diritti. Turin: Einaudi.

Busani, A., and Smaniotto, E., 2018. No alle cure senza «Dat», rischio incostituzionalità. Il Sole 24 Ore [online], 18 April. Available from: http://www.notaiobusani.it/Handlers/Document.ashx?ID=27668331-835d-4c60-ba92-9e6a539e0396 [Accessed 29 May 2019].

Busatta, L., 2019. A un anno dalla legge 219 del 2017: la sostenibilità costituzionale della relazione di cura. Rivista AIC [online], 2/2019, 95-115 [online]. Available from: https://www.rivistaaic.it/it/rivista/ultimi-contributi-pubblicati/luciabusatta/a-un-anno-dalla-legge-219-del-2017-la-sostenibilita-costituzionale-dellarelazione-di-cura [Accessed 29 May 2019].

Caramaschi, G., and Capanna Piscè, G., 2008. Mutamento sociale, morte e genesi dell'individuo contemporaneo. Terri Schiavo e l'eutanasia nei media. In: A. Agustoni, ed., Intorno al mondo nuovo: Modernità e mutamento culturale. Rome: Aracne, 159-176.

Castorina, R., 2011. Bioeconomia. La microfisica delle condotte nell'era globale. Metábasis: Filosofia e comunicazione, $\mathrm{n}^{\mathrm{o}}$. 11.

Castorina, R., 2013a. Antropogenesi ed unità tragica. In: R. Castorina and G. Roccheggiani, eds., Paradossi della fragilità: Critica della normalizzazione sociale tra neuroscienze e filosofia politica. Milan/Udine: Mimesis.

Castorina, R., 2013b. Pensare e vivere il "fuori". Etopolitica, ontologia e scrittura nella riflessione di Michel Foucault. Lo Sguardo - Rivista di Filosofia, 11, 2013 (I).

Castorina, R., 2016. Medicalizzazione e società neoliberale. Riflessioni critiche a partire da "Salute/malattia" di Franca Ongaro Basaglia. Quaderni di inchiesta sociale [online], 18 May. Available from:

http://www.inchiestasociale.it/2016/05/18/medicalizzazione-e-societa-neoliberale/ [Accessed 29 May 2019].

Codeluppi, V., 2008. Il biocapitalismo: Verso lo sfruttamento integrale di corpi, cervelli ed emozioni. Turin: Bollati Boringhieri.

Conrad, P., 2007. The Medicalization of Society: On the Transformation of Human Conditions into Treatable Disorders. Baltimore: Johns Hopkins University Press. 
Consiglio di Stato, Commissione speciale del 18 luglio 2018, n․ 1991 [online]. Available from: https://www.giustiziaamministrativa.it/cdsintra/wcm/idc/groups/public/documents/document/mday/o dm0/ edisp/46hxmdk5wuoh565h75ebukeoxe.html [Accessed 29 May 2019].

Constitution of the World Health Organization, 1946 [online]. Available from: https://www.who.int/governance/eb/who constitution en.pdf [Accessed 29 May 2019].

Constitutional Court, Ord. no. 207/2018 [online]. Available from: http://www.diritto24.ilsole24ore.com/ Allegati/Free/Ordinanza 207.pdf [Accessed 29 May 2019].

Convention for the Protection of Human Rights and Dignity of the Human Being with regard to the Application of Biology and Medicine: Convention on Human Rights and Biomedicine. Oviedo, 4 April 1997. European Treaty Series [online], № 164.

Available from: https://rm.coe.int/168007cf98 [Accessed 29 May 2019].

Corriere della Sera, 2018. Dj Fabo, il Governo si costituisce alla Consulta per la legittimità del reato di aiuto al suicidio nel processo Cappato. Corriere della Sera [online], 3 April. Available from:

https://milano.corriere.it/notizie/cronaca/18 aprile 03/dj-fabo-governo-sicostituisce-consulta-la-legittimita-reato-aiuto-suicidio-processo-marco-cappato0944d3ae-3737-11e8-b6e2-a808a444e7a2.shtml?refresh_ce-cp [Accessed 29 May 2019].

Corsi, G., 2015a. Introduzione. Malattia e salute: il contributo della teoria dei sistemi. In: G. Corsi, ed., Salute e malattia nella teoria dei sistemi: A partire da Niklas Luhmann. Milan: Franco Angeli, 9-39.

Corsi, G., 2015b. Levando o indivíduo a sério. A relação indivíduo-sociedade na teoria dos sistemas. Tempo social [online], (27)2, 181-198. Available from: http://dx.doi.org/10.1590/0103-2070201529 [Accessed 29 May 2019].

Court of Assizes of Milan, Ord. 14/02/2018 [online]. Available from: https://www.associazionelucacoscioni.it/wp-content/uploads/2017/11/OrdinanzaCorte-di-Assise-Milano-Processo-Cappato.pdf [Accessed 29 May 2019].

Crawford, R., 1980. Healthism and the medicalization of everyday life. International Journal of Health Services [online], 10(3), 365-388. Available from: http://doi.org/10.2190/3H2H-3XJN-3KAY-G9NY [Accessed 29 May 2019].

Crist, C., 2017. Over one third of U.S. adults have advanced medical directives. Reuters [online], 11 July. Available from: https://www.reuters.com/article/us-health-usaadvance-directives/over-one-third-of-u-s-adults-have-advanced-medicaldirectives-idUSKBN19W2NO [Accessed 29 May 2019].

Cruz Balbuena, L., 2018. The Foruen Enparantza in Oñati as an Illustration. Oñati SocioLegal Series [online], 7(6). Available from:

http://opo.iisj.net/index.php/osls/article/view/940 [Accessed 29 May 2019].

Dardot, P., and Laval, C., 2017. The New Way of the World: On Neoliberal Society. New York: Verso. 
Donaggio, E., 2014. Prefazione. In: L. Boltanski and È. Chiapello, eds., Il nuovo spirito del capitalismo. Milan/Udine: Mimesis.

Esposito, R., 2003. Biopolitica, immunità, comunità. In: L. Bazzicalupo and R. Esposito, eds., Politica della vita: Sovranità, biopotere, diritti. Rome/Bari: Laterza.

Esposito, R., 2004. Bíos: biopolitica e filosofia. Turin: Einaudi.

Esposito, R., 2007. Terza persona: Politica della vita e filosofia dell'impersonale. Turin: Einaudi.

Esposito, R., 2014. Le persone e le cose. Turin: Einaudi.

Fagerlin, A., and Schneider, C.E., 2004. Enough: The Failure of the Living Will. Hastings Center Report [online], 34, no. 2, 30-42. Available from:

https://hods.org/pdf/Enough The\%20Failure\%20of\%20the\%20Living\%20Will.pdf [Accessed 29 May 2019].

Focus MGMT-Vidas, 2018. Indagine conoscitiva sulle percezioni in merito al Testamento Biologico: Focus sui cittadini lombardi [online]. Report. Milan, 3 December.

Available from: https://www.vidas.it/wpcontent/uploads/Ricerca testamento biologico.pdf [Accessed 29 May 2019].

Foucault, M., 1978. The Will to Knowledge: The History of Sexuality (volume 1). New York: Pantheon Books.

Foucault, M., 1980. The Confession of the Flesh. In: C. Gordon, ed., Power/Knowledge: Selected Interviews \& Other Writings: 1972-1977. New York: Pantheon Books.

Foucault, M., (with F. Gros, ed.), 2005. The Hermeneutics of the Subject: Lectures at the Collège de France 1981-1982. Trans.: G. Burchell. New York: Picador.

Foucault, M., (with M. Senellart, ed.), 2008. The Birth of Biopolitics: Lectures at the Collctu de France, 1978-1979. London: Palgrave: Macmillan.

Habermas, J., 1996. Fatti e norme. Milan: Guerini e Associati.

Han, B.C., 2012. La società della stanchezza. Trans.: F. Buongiorno. Rome: Nottetempo.

Han, B.C., 2014a. La società della trasparenza. Trans.: F. Buongiorno. Rome: Nottetempo.

Han, B.C., 2014b. Why revolution is no longer possible. Süddeutsche Zeitung [online], 2 September. Available from:

https://www.opendemocracy.net/transformation/byung-chul-han/whyrevolution-is-no-longer-possible [Accessed 29 May 2019].

Han, B.C., 2017a. Psychopolitics: Neoliberalism and New Technologies of Power. London: Verso.

Han, B.C., 2017b. The Agony of Eros. Trans.: E. Butler. Cambridge, MA: The MIT Press.

Harvey, D., 2005. A Brief History of Neoliberalism. Oxford University Press.

Hegel, G.W.F., 2019. The Phenomenology of Spirit. Cambridge University Press.

Henderson, S., and Petersen, A., 2000. Introduction: consumerism in health care. In: S. Henderson and A. Petersen, eds., Consuming Health: The Commodification of Health Care. Abingdon: Routledge, 1-10. 
Kant, I., 2013. The Metaphysics of Morals. Cambridge University Press.

Law $n^{\circ} .219$, approved on December, 22, 2017. Norme in materia di consenso informato e di disposizioni anticipate di trattamento [online]. Entry into force on 31 January 2018. Available from: http://www.gazzettaufficiale.it/eli/id/2018/1/16/18G00006/sg [Accessed 28 April 2018].

Lenzi, D., 2018. La legge 219/2017 e il difficile percorso parlamentare. Diritto e salute. Rivista di sanità e responsabilità medica [online], 4, 99-117. Available from: http://www.dirittoesalute.org/2018/10/30/la-legge-219-2017-e-il-difficile-percorsoparlamentare/[Accessed 29 May 2019].

Longo, M., 2001. Strutture della società e semantica del soggetto. Lecce: Pensa Multimedia. Losurdo, F., 2018. L'ultima scelta. Dogmatiche dell'autodeterminazione e fine vita. Rivista elettronica del Centro di Documentazione Europea dell'Università Kore di Enna [online], 12, 1. Available from: https://www.unikore.it/index.php/koreuropa12/losurdo [Accessed 29 May 2019].

Luhmann, N., 1992. The concept of society. Thesis Eleven [online], 31(1), 67-80. Available from: https://doi.org/10.1177\%2F072551369203100106 [Accessed 29 May 2019].

Luhmann, N., 1995a. Die Form „Person”. In: N. Luhmann, Soziologische Aufklärung. Bd. 6: Die Soziologie und der Mensch. Opladen: Westdeutscher, 142-154.

Luhmann, N., 1995b. Individuo, Individualidad, Individualismo. Zona Abierta, 70-71, 53-157.

Luhmann, N., 1997. Die Gesellschaft der Gesellschaft. Frankfurt: Suhrkamp.

Luhmann, N., 2002. I diritti fondamentali come istituzioni. Trans.: S. Magnolo. Bari: Dedalo.

Luhmann, N., 2015a. Il codice della medicina. In: G. Corsi, ed., Salute e malattia nella teoria dei sistemi: A partire da Niklas Luhmann. Milan: Franco Angeli, 40-51.

Luhmann, N., 2015b. Inflazione di pretese nel sistema delle malattie: una presa di posizione dal punto di vista della teoria della società: In: G. Corsi, ed., Salute e malattia nella teoria dei sistemi: A partire da Niklas Luhmann. Milan: Franco Angeli, $52-70$.

Manfré, G., 2014. Per la critica della cultura della valutazione. Bologna: Emil de Odoya.

Morrone, A., 2018. Il "caso Cappato" davanti alla Corte costituzionale. Riflessioni di un costituzionalista. Lecture. In: Università di Bologna, Il "caso Cappato" davanti alla Corte costituzionale [online], 3-13. Preventive seminary. Bologna, 12 October.

Available from: http://www.forumcostituzionale.it/wordpress/wpcontent/uploads/2018/10/caso-cappato_amici-curiae.pdf [Accessed 29 May 2019].

Nietzsche, F., 1993. The Birth of Tragedy. London: Penguin.

Orestano, R., 1950. Diritti soggettivi e diritti senza soggetto: Linee di una vicenda concettuale. Jus, XI, 149-196. 
Paris, D., 2018. Dal diritto al rifiuto delle cure al diritto al suicidio assistito (e oltre). Brevi osservazioni all'ordinanza n⿳o ${ }^{\circ}$ 207/2018 della Corte costituzionale. Corti supreme e salute [online], 3, 1-11. Available from:

http://www.cortisupremeesalute.it/wp-content/uploads/2019/03/Paris-Dal-dirittoal-rifiuto-delle-cure-al-diritto-al-suicidio-assistito-e-oltre.-Brevi-osservazioniall\%E2\%80\%99ordinanza-n.-2072018-della-Corte-costituzionale-1.pdf [Accessed 29 May 2019].

Peces-Barba Martínez, G., (with V. Ferrari, ed.), 1993. Teoria dei diritti fondamentali. Milan: Giuffrè.

Rabinow, P., and Rose, N., 2006. Thoughts on the concept of biopower today. Biosocieties: An interdisciplinary journal for the social study of the life sciences [online], I(2), 195-217. Available from: http://dx.doi.org/10.1017/S1745855206040014 [Accessed 29 May 2019].

Read, J., 2009, A Genealogy of Homo-Economicus: Neoliberalism and the Production of Subjectivity. Foucault Studies [online], 6, 25-36. Available from: https://rauli.cbs.dk/index.php/foucault-studies/article/download/2465/2463 [Accessed 29 May 2019].

Rodotà, S., 2012. Il diritto di avere diritti. Rome/Bari: Laterza.

Rose, N., 1999a. Governing the Soul: The Shaping of the Private Self. $2^{\text {nd }}$ ed. London/New York: Free Association Books.

Rose, N., 1999b. Powers of Freedom: Reframing Political Thought. Cambridge University Press.

Silchenko, K., 2017. Powered by Health: Healthism in Food Marketing and Consumer Research. A Systematic Review and a Critical Discourse Analysis [online]. PhD Thesis, Economics and Management-Social Sciences. Management and Accounting. Università degli Studi di Macerata, Dipartimento di Economia e Diritto. Available from: https://upad.unimc.it/retrieve/handle/11393/238230/38607/SILCHENKO_PhD\%20thesis.p df [Accessed 29 May 2019].

Simmel, G., 1971. Freedom at the Individual. In: D.N. Levine, ed., On Individuality and Social Forms. Chicago/London: The University of Chicago Press, 217-226.

Simon, F.B., 1994. La distinzione malato/sano. Sulla forma dell'osservazione terapeutica. Teoria sociologica, 2, 233-243.

Spencer-Brown, G., 2014. Laws of Form. Leipzig: Bohmeier.

Supiot, A., 2005. Homo juridicus : Essai sur la fonction anthropologique du Droit. Paris: Éditions du Seuil.

Teno, J., et al., 1997. Do Advance Directives Provide Instructions that Direct Care? SUPPORT Investigators. Study to Understand Prognoses and Preferences for Outcomes and Risks of Treatment. Journal of the American Geriatrics Society [online], 45(4), 508-512. Available from: https://www.ncbi.nlm.nih.gov/pubmed/9100722 [Accessed 29 May 2019]. 
Testoni, I., et al., 2014. Life at all costs? Italian social representations of end-of-life decisions after president Napolitano's speech - margin notes on withdrawing artificial nutrition and hydration. Nutritional Therapy and Metabolism [online], 32(3), 121-135. Available from: https://doi.org/10.5301/NTM.2014.12488 [Accessed 29 May 2019].

Tribunale di Roma, Sezione I Civile, ordinanza 15-16 dicembre 2006 [online]. Available from: https://www.eius.it/giurisprudenza/2006/150 [Accessed 29 May 2019].

Tripodina, C., 2018. Quale morte per gli “immersi in una notte senza fine"? Sulla legittimità costituzionale dell'aiuto al suicidio e sul "diritto a morire per mano d'altri". BioLaw Journal - Rivista di BioDiritto [online], no. 3. Available from: http://doi.org/10.15168/2284-4503\%2F334 [Accessed 29 May 2019].

Vial, S.R.M., 2014. O sistema social da saúde: conceito, limites e possibilidades. Cadernos Ibero-Americanos de Direito Sanitário [online], (3)1, 68-83. Available from: http://doi.org/10.17566/ciads.v3i1.19 [Accessed 29 May 2019].

Vial, S.R.M., 2015. Construção do sistema social da saúde a partir da Teoria Sistêmica de Niklas Luhmann. Revista de Direito Sanitário [online], (16)1, 112-127. Available from: https://doi.org/10.11606/issn.2316-9044.v16i1p112-127 [Accessed 29 May 2019].

White, K., 2002. An Introduction to the Sociology of Health and Illness. London/Thousand Oaks/New Delhi: Sage.

Zagrebelsky, G., 2018. Il diritto che obbedisce alla vita. La Repubblica [online], 22 February, 40-41. Available from:

https://ricerca.repubblica.it/repubblica/archivio/repubblica/2018/02/22/il-dirittoche-obbedisce-alla-vita01.html [Accessed 29 May 2019].

Zuppiroli, A., 2005. Riduzionismo medico e senso della cura. In: G. Marrone, ed., Il discorso della salute: Verso una sociosemiotica medica. Atti del XXXII Congresso della Associazione Italiana di Studi Semiotici, Spoleto, 29 ottobre - 1 novembre 2004. Rome: Meltemi, 100-108. 